\title{
Lyophilized Powder of Hibiscus sabdariffa (Roselle) Extracts using Gum Arabic and Maltodextrin as Carrier Agents
}

\author{
Sandro Cid-Ortega ${ }^{1,2}$ \& José Ángel Guerrero-Beltran ${ }^{1}$ \\ ${ }^{1}$ Departamento de Ingeniería Química, Alimentos y Ambiental, Fundacion Universidad de las Americas Puebla, \\ Ex hacienda Sta. Catarina Mártir, Cholula, Puebla 72810, Mexico \\ ${ }^{2}$ Programa Educativo de Ingeniería en Procesos Alimentarios, Universidad Tecnológica de Izúcar de Matamors, \\ Izúcar de Matamoros, Puebla, México \\ Correspondence: Jose Angel Guerrero-Beltran, Departamento de Ingeniería Química, Alimentos y Ambiental. \\ Fundacion Universidad de las Americas Puebla. Ex hacienda Sta. Catarina Mártir, Cholula, Puebla 72810, \\ Mexico. Tel: 52-222-229-2126. E-mail: angel.guerrero@udlap.mx; joseangel150@hotmail.com
}

Received: December 15, 2021

Accepted: January 22, $2021 \quad$ Online Published: February 10, 2021

doi:10.5539/jfr.v11n2p1

URL: https://doi.org/10.5539/jfr.v11n2p1

\begin{abstract}
Freeze-drying is a process for drying foods without heat application. The physical, chemical and sensory properties of the food remain without significant changes. In this work, maltodextrin (MD), gum arabic (GA), and a blend of $M D: G A(60: 40)$ were used as encapsulating agents of Roselle (Hibiscus sabdariffa) calyces extracts. Lyophilized powders were obtained at different concentrations of encapsulating agent $(0,3,5$, and $10 \%$, w/w). Powders were analyzed in yield and physicochemical (average size diameter $\left(\mathrm{d}_{50}\right)$, moisture content, water activity $\left(a_{w}\right)$, bulk and compacted densities, and color), and antioxidants (anthocyanins content, total phenolic compounds, antioxidant capacity) characteristics. The yields of freeze-drying powders from different encapsulating agents ranged 82 to $95 \%$. The average diameter $\left(\mathrm{d}_{50}\right)$ was higher for powders without gum $(139.5 \pm 25.6 \mu \mathrm{m})$ than for powders with encapsulating agents (35 to $89 \mu \mathrm{m})$. The moisture content and $a_{w}$ of the powders were in the ranges 5.3-11.2\% and 0.20-0.29, respectively. The value of the red ( $\left.a^{*}\right)$ color parameter of all powders was $37.0 \pm 2.8$, decreasing as increasing the gums concentration. Powders with $3 \% G A$ and $M D$ showed the highest amount of anthocyanins: $560.93 \pm 10.13$ and $543.46 \pm 15.68 \mathrm{mg} / 100 \mathrm{~g}$ of powder, respectively. The highest total phenolic compounds content was observed in the powder with the $3 \%$ MD:GA blend $(4,705.70 \pm 140.54 \mathrm{mg} / 100 \mathrm{~g}$ of powder). Powder with $3 \% \mathrm{MD}$ showed the highest antioxidant capacity $(1,766.30 \pm 31.15 \mathrm{mg}$ of Trolox equivalents/100 g powder).
\end{abstract}

Keywords: microencapsulation, freeze-drying, Hibiscus sabdariffa powders, maltodextrin, gum arabic, anthocyanins, phenolic compounds, antioxidant capacity

\section{Introduction}

The encapsulation of food compounds is used to reduce their degradation due to environmental factors (such as oxygen, light, temperature and pro-oxidants) to improve their stability during processing or to control their release in the food system (Santos and Meireles, 2010). Encapsulating agents include natural polymers or lipids. Maltodextrins and gum arabic are the most commonly used encapsulating agents in spray drying for obtaining microencapsulates. Maltodextrins provide low viscosities at high concentrations and good solubility; however, its emulsifying capacity is low. Maltodextrins in a range of 10 to 20 equivalent of dextrose are the most appropriate. On the other hand, gum arabic is a very efficient encapsulating agent; it is a polymer which has $2 \%$ protein in its structure providing excellent emulsifying properties; however, at high concentrations its viscosity increases (Gharsallaoui et al., 2007). It has been seen that mixtures of these two carrier agents may provide better results in spray drying (Zhang et al., 2007; Lopez et al., 2009; Idham et al., 2012; Fazaeli et al., 2012).

Microencapsulation is a widely used process in the food, pharmaceutical, and cosmetics industries, as well as in agricultural, veterinary, medical, chemical, biotechnological, and biomedical fields. Spray drying is a widely used economical method for encapsulating food ingredients. Particle sizes of powders obtained by this method are generally in the range of $10-50 \mu \mathrm{m}$; however, this size may depend on the process conditions (Gharsallaoui et al., 2007). The main advantages of this process, besides its simplicity, are its suitability for use with heat-sensitive materials because the time required at high temperatures is very short (5-30 s) (Ochoa-Velasco et 
al., 2017), the equipment needed is readily available, options for encapsulating materials are many, the encapsulation process is efficient, the final product is stable, and there is the potential for continuous large-scale production (Santos and Meireles, 2010). The parameters that have great influence in the spray drying process are nozzle geometry, viscosity of the feeding solution, and the inlet and outlet air temperatures (Munin and Edwards-Lévy, 2011; Gharsallaoui et al., 2007). Commercially, this technique has been used to encapsulate numerous materials, including flavor agents, fats, oils, vitamins, minerals, microorganisms, enzymes, sweeteners, and colorants (Wijaya et al., 2011).

Freeze drying (lyophilization) is a preservation method where water is evaporated or eliminated by the application of vacuum and low temperatures in the processing system. It consists of evaporating water from a frozen material (sublimation) without passing through the liquid state. Lyofilization is a way to dry heat labile chemicals or food products. This preservation procedure is used for the production of milk for infants, soups, coffee, infusions, the commercial preparation of antibiotics, some vaccines, many foods and flavor products. The main advantage of this method is that products being dehydrated in a frozen state retain their shape, aroma, flavor, vitamins, nutritional value, and active ingredients. In addition, it could be appliable to most foods, facilitating their productions on site with minimal transport costs. However, it is a prolonged and expensive method (Santos and Meireles, 2010; Özkan and Bilek, 2014). Nowadays, in addition to the products above mentioned, the process is being used to obtain powders of extracts from parts of plants in order to evaluate their antioxidant, antimicrobial and coloring properties (Rajarajan et al., 2010; Viloria-Matos et al., 2002; Muro et al., 1997).

There is little research on this technique for obtaining powders from Hibiscus sabdariffa extracts. Some studies have shown that powders obtained by freeze drying, using maltodextrin (mainly) as encapsulating agent, have great stability maintaining their antioxidant properties; therefore, being these powders an option for use them as colorants and flavorings for foods (Duangmal et al., 2004; Selim et al., 2008).

The aim of this work was to evaluate the effect of maltodextrin and gum arabic as encapsulating agents for obtaining lyophilized powders of extracts of Hibiscus sabdariffa calyces.

\section{Materials and Methods}

\subsection{Material}

Calyces from creole Hibiscus sabdariffa long red variety, grown in Chiautla de Tapia, Puebla, Mexico, were used. The Roselle calyces powder $(R C P)$ was obtained using a Veyco stainless steel mill model MPV 100 (Mexico) with a mesh of $0.5 \mathrm{~mm}$.

\subsection{Methods}

\subsubsection{Average Particle Size}

The average particle size was carried out using a Microtac S3500 particle size analyzer (Microtac Inc., Largo, FL, USA) in a range of 0.25 to $2,800 \mu \mathrm{m}$. The analysis was carried out in triplicate using approximately $60 \mathrm{mg}$ of Roselle calyces powder $(R C P)$ or $40 \mathrm{mg}$ of lyophilized powder $(L P)$. Curves of granulometry, accumulative retained weight, and average diameter $\left(\mathrm{d}_{50}\right)$ were obtained (O'Hagan et al., 2005; Cid-Ortega and Guerrero-Beltrán, 2020).

\subsubsection{Roselle Extracts Concentrates $(R E C)$}

The Roselle extracts $(R E)$ were carried out at $50 \pm 0.2^{\circ} \mathrm{C}$ for $30 \mathrm{~min}$ according to Chumsri et al. (2008) and Cid-Ortega and Guerrero-Beltrán (2020) methods using a Riossa M80T Water Bath (Rios Rocha S.A., Monterrey, Nuevo León, Mexico). The Roselle:solvent ratio was 1:10 (20 g of Roselle powder $+200 \mathrm{~mL}$ of 50\% ethanol). Mixtures were filtered through Whatman paper No. 4 and placed in $250 \mathrm{~mL}$ flasks wrapped with aluminum foil (Cid-Ortega and Guerrero-Beltrán, 2020). Afterward, the ethanol was removed, for obtaining Roselle extracts concentrates (REC), using a Büchi RE 111 rotary evaporator (Brinkmann Instruments Inc., Switzerland) at $45 \pm$ $1^{\circ} \mathrm{C}$ and $54 \mathrm{cmHg}$ of vacuum for no more than $45 \mathrm{~min}$ (Selim et al., 2008). The RECs were analyzed in antioxidant characteristics (total anthocyanins, total phenols, and antioxidant capacity).

\subsubsection{Roselle Extracts Concentrates-gums (RECG)}

A 3x3 factorial design was used in this study. Three types of gums or blends (gum arabic powder from Roller Dry (Central de Drogas S.A. de C.V., State of Mexico, Mexico), maltodextrin ED: 9-14 (CP Ingredientes S.A. de C.V., Guadalajara, Mexico), and a blend of maltodextrin:gum arabic in a proportion of 60:40)) and three concentrations of gums $(3,5$, and $10 \% \mathrm{w} / \mathrm{w})$ were used. The gum was added to each free-ethanol extract and stirred for $15 \mathrm{~min}$ at room temperature $\left(22 \pm 2^{\circ} \mathrm{C}\right)$ to obtain the RECG. The RECGs were placed into $250 \mathrm{~mL}$ 
flasks, covered with aluminum foil and stored in refrigeration $\left(4^{\circ} \mathrm{C}\right)$ until drying. A control was also prepared (extract without ethanol and gum). Total soluble solids, density and viscosity were analyzed.

\subsubsection{Lyophilization}

The RECGs were placed in Petri dishes $(13.76 \pm 0.07 \mathrm{~cm}$ in diameter), covered with aluminum foil and frozen for a minimum of 72 hours in a CHTC-16E horizontal freezer (Torrey, Mexico) at $-26 \pm 0.5^{\circ} \mathrm{C}$. The frozen $R E C G$ were lyophilized in a LabConco freeze drier (LabConco Corp. Kansas, City, USA) at $20^{\circ} \mathrm{C}$ and 0.005 to 0.01 $\mathrm{mmHg}$ of vacuum for 72 hours. The lyophilized $R E C G$ (Roselle powders $=R P$ ) were weighed, pulverized, placed in amber pharmaceutical jars, sealed with plastic wrap and capped. $R P$ were stored in a desiccator with silica at room temperature $\left(22 \pm 2^{\circ} \mathrm{C}\right)$.

2.2.5 Physicochemical Properties of Extracts

\section{Total soluble solids (TSS)}

They were measured according to the 932.14C AOAC (1995) method. A manual Atago Master-M model refractometer (Atago Co. LTD., Tokyo, Japan) with a scale of $0-32^{\circ} \mathrm{Bx}$ was used. The readings were corrected at $20^{\circ} \mathrm{C}$ using the values established in the reference tables of the AOAC (1995).

Density. It was determined by the 945.06 AOAC (1995) method. $10 \mathrm{~mL}$ pycnometers were used. Empty pycnometers $\left(W_{1}\right)$, pycnometers filled with distilled water $\left(W_{2}\right)$, and pycnometers with the sample $\left(W_{3}\right)$ were weighed. The density $\left(25^{\circ} \mathrm{C}\right)$ was calculated according to Eq. (1):

$$
\rho(g / m L)=\left[\frac{W_{2}-W_{1}}{W_{3}-W_{1}}\right] * \rho_{H_{2} O}^{25^{\circ} \mathrm{O}}
$$

where $\rho_{\mathrm{H}_{2} \mathrm{O}}^{25^{\circ} \mathrm{C}}(\mathrm{g} / \mathrm{mL})$ is the density of water at $25^{\circ} \mathrm{C}$.

Absolut viscosity $(\mu)$

A 350-159I Cannon Fenske capillary viscometer (Cannon Instrument Co., State College, PA, USA) was used. The kinematic viscosity was obtained by multiplying the flow time (seconds) of $6.6 \mathrm{~mL}$ of extract at $40^{\circ} \mathrm{C}$ by the constant of the viscometer $\left(0.4754 \mathrm{~mm}^{2} / \mathrm{s}^{2}\right)$ at the same temperature. For calculating the absolute viscosity $(\mu)$, Eq. (2) was used (Cannon Instrument Company, 2000):

$$
\mu(c P)=\rho_{s} * v_{c}
$$

where $\rho_{s}(\mathrm{~g} / \mathrm{mL})$ is the density of the extract and $v_{c}\left(\mathrm{~mm}^{2} / \mathrm{s}=\mathrm{cSt}\right)$ is the kinematic viscosity.

\subsubsection{Antioxidant Characteristics}

\section{Total monomeric anthocyanins (TMA)}

The TMAs determination was carried out according to the Lee et al. (2005) method with some modifications according to Cid-Ortega and Guerrero-Beltrán (2020). Briefly, $0.5 \mathrm{~mL}$ of extract or $100 \mathrm{mg}$ of powder were used, made up to $10 \mathrm{~mL}$ with distilled water and totally homogenized with a Vortex (2900 to $3000 \mathrm{rpm}$ ) for $5 \mathrm{~min}$; these are the Roselle extract solution (RES) or the powder solution $(P S)$. Then, $1 \mathrm{~mL}$ of solution was taken and mixed with $4 \mathrm{~mL}$ of buffer $\mathrm{pH} 1$ or $\mathrm{pH} 4.5$. The solutions were allowed to stand for 30 minutes at room temperature $\left(22 \pm 2^{\circ} \mathrm{C}\right)$. The absorbances were measured at 520 and $700 \mathrm{~nm}$ in a Cary $100 \mathrm{UV}$-visible spectrophotometer (Varian Inc., Palo Alto, CA, USA). A blank with distilled water was used for standardizing the equipment. Results were reported as equivalents of cyanidin-3-glucoside (C-3-G) per $100 \mathrm{~mL}$ of extract or per $100 \mathrm{~g}$ of powder according to Eq. (3).

$$
T M A=\frac{A * M W * D F}{\varepsilon * L} * 100
$$

where TMA is the total monomeric anthocyanins content $(\mathrm{mg} / 100 \mathrm{~mL}$ or $\mathrm{mg} / 100 \mathrm{~g}) ; A=\left(\mathrm{A}_{520 \mathrm{~nm}}-\mathrm{A}_{700 \mathrm{~mm}}\right)_{\mathrm{pH}=1.0}$ $\left(\mathrm{A}_{520 \mathrm{~nm}}-\mathrm{A}_{700 \mathrm{~nm}}\right)_{\mathrm{pH}=4.5} ; M W$ is the molecular weight of cyanidin-3-glucoside $(449.2 \mathrm{~g} / \mathrm{mol}) ; F D$ is the dilution factor; $L$ is the cell pathway $(1 \mathrm{~cm}) ; \varepsilon$ is the molar extinction coefficient of cyanidin-3-glucoside $(26,900$ $\mathrm{L} / \mathrm{mol}^{*} \mathrm{~cm}$ ); 100 is the conversion factor of $\mathrm{mg} / \mathrm{mL}$ or $\mathrm{mg} / \mathrm{g}$ to obtain $\mathrm{mg} / 100 \mathrm{~mL}$ or $\mathrm{mg} / 100 \mathrm{~g}$, respectively.

Total phenolic compounds (TPC) 
They were determined by the method reported by Singleton and Rossi (1965) method with some modifications according to Cid-Ortega and Guerrero-Beltrán (2020). Briefly, $3 \mathrm{~mL}$ of distilled water, $150 \mu \mathrm{L}$ of Roselle extract solution $(R E S)$ or $100 \mu \mathrm{L}$ of powder solution $(P S)$ were placed in test tubes (covered with aluminum foil), separately, mixed with a Vortex (2,900 at 3,000 rpm) for $5 \mathrm{~min}$. Then, $250 \mu \mathrm{L}$ of Folin-Ciocalteu reagent were added, completely mixed and left for 8 minutes in the dark. Finally, $750 \mu \mathrm{L}$ of $20 \% \mathrm{Na}_{2} \mathrm{CO}_{3}$ was added and made up to $5 \mathrm{~mL}$ with distilled water. Mixtures were left for 2 hours at room temperature $\left(21 \pm 1^{\circ} \mathrm{C}\right)$ in the dark. The absorbances were then measured at $765 \mathrm{~nm}$ in a Cary $100 \mathrm{UV}$-visible spectrophotometer (Varian Inc., Palo Alto, CA, USA). A standard curve was prepared in duplicate at different concentrations of gallic acid (98.5\%, Sigma): 0 - $66.4 \mu \mathrm{g}$. Abs $=17.50 \pm 2.36(1 / \mathrm{mg}$ gallic acid $) \mathrm{X}(\mathrm{mg}$ gallic acid $)+0.018 \pm 0.011\left(\mathrm{R}^{2}=0.998 \pm 0.001\right)$. Total phenolic compounds (TPC) were reported as gallic acid equivalents $(G A E)$ per $100 \mathrm{~mL}$ of extract or $100 \mathrm{~g}$ of powder according to Eq. (4).

$$
T P C=\frac{A-b}{m} * D F * 100
$$

where $A$ is the absorbance of the sample, $b$ is the intercept, $m$ is the slope and $D F$ is the dilution factor.

\section{Antioxidant capacity $(A C)$}

The DPPH (1,1-diphenyl-1-picrylhydrazyl) method (Brand-Williams et al., 1995) was used with some modifications (Cid-Ortega and Guerrero-Beltrán, 2020). Briefly, $2 \mathrm{~mL}$ of RES or $1.6 \mathrm{~mL} P S$ were taken and diluted with ethanol (99.5\%) to make up $10 \mathrm{~mL}$ in a volumetric flask, mixed with a Vortex (2,900 to 3,000 rpm) for $5 \mathrm{~min}$ and then filtered (twice) through Whatman paper No. 5. From the filtrates, $1 \mathrm{~mL}$ was taken and mixed, in a test tube (covered with aluminum foil), with $1 \mathrm{~mL}$ of ethanol (99.5\%) and $2 \mathrm{~mL}$ of DPPH solution $(7.8 \pm 0.2$ $\mathrm{mg}$ in $200 \mathrm{~mL}$ of $99.5 \%$ ethanol), perfectly mixed and allowed to stand for $45 \mathrm{~min}$ at room temperature (21 \pm $2^{\circ} \mathrm{C}$ ) in the dark. Absorbances were measured at $517 \mathrm{~nm}$ using a Cary $100 \mathrm{UV}$-visible spectrophotometer (Varian Inc., Palo Alto, CA, USA). The antioxidant capacity $(A C)$ was calculated as percentage of inhibition according to Eq. (5).

$$
I(\%)=\frac{A c-A s}{A c} * 100
$$

where $A c$ is the absorbance of the control and $A s$ is the absorbance of the sample. A standard curve was prepared in duplicate with different concentrations of trolox (6-hydroxy-2, 5, 7, 8 tetramethylchrome-2, 97\% carboxylic acid, Aldrich) $(\mathrm{T}): 0-28.7 \mu \mathrm{g}$. I $(\%)=3278.9 \pm 195.8(1 / \mathrm{mg} \mathrm{T}) \mathrm{X}(\mathrm{mg} \mathrm{T})+2.9 \pm 1.3 . \mathrm{R}^{2}=0.989 \pm 0.007$. Results were expressed as trolox equivalents (TE) per $100 \mathrm{~mL}$ of extract or per $100 \mathrm{~g}$ of powder, according to Eq. (6).

$$
A C=\frac{A-b}{m} * D F * 100
$$

where $A$ is the absorbance of the sample, $b$ is the intercept, $m$ is the slope and $D F$ is the dilution factor.

\subsubsection{Physicochemical Properties of Powders}

\section{Yield $(Y)$.}

It was calculated according to the amount of total soluble solids (TSS) in the encapsulated extract and the amount of powder obtained (Fazaeli et al., 2012), according to Eq. (7).

$$
Y(\%)=\frac{\text { Amount of powder }}{\text { Amount of } T S S} * 100
$$

\section{Moisture content}

It was determined according to the 934.06 AOAC (2000) method. A Cole Parmer vacuum oven (Chicago, Illinois, USA) was used. The sample $(1.0 \pm 0.003 \mathrm{~g})$ was dried for 8 hours at $70 \pm 1^{\circ} \mathrm{C}$ at a vacuum pressure of 200 to 220 mmHg.

Water activity $\left(a_{w}\right)$

It was measured using an AQUA-LAB hygrometer model 3TE (Decagon Devices Inc. Pullman, Washington, USA) with internal control of temperature. The equipment was calibrated with distilled water and charcoal (Decagon Devices Inc., 2008). The $a_{w}$ of powder was measured at $25.1 \pm 0.06^{\circ} \mathrm{C}$.

Bulk density $\left(\rho_{\mathrm{b}}\right)$. It was determined according to the Jumah et al. (2000) method. One gram of powder was placed in a $10 \mathrm{~mL}$ graduated cylinder. The sample was tapped ten times (on a polystyrene base) from a height of 
$15 \mathrm{~cm}$. The bulk density was calculated according to Eq. (9).

$$
\rho_{\mathrm{b}}=\frac{W}{V_{\mathrm{a}}}
$$

where $W(\mathrm{~g})$ is the weight of the powder and $V_{a}(\mathrm{~mL})$ is the volume occupied by the powder.

\section{Tap density $\left(\rho_{\mathrm{t}}\right)$}

It was carried out according to the method reported in the Official Mexican Norm NOM-104-STPS-2001 (NOM, 2001), with some modifications. One gram of powder was placed in a $10 \mathrm{~mL}$ graduated cylinder and topped with a rubber stopper. Then, the sample was tapped from bottom to top for $8 \mathrm{~min}$ (time in which volume was no longer changed). The tap density was calculated according to Eq. (9).

$$
\rho_{\mathrm{t}}=\frac{W}{V_{\mathrm{t}}}
$$

where $W(\mathrm{~g})$ is the weight of the powder and $V_{t}(\mathrm{~mL})$ is the compacted volume occupied by the powder.

Color

A Colorgard system 05 colorimeter (BYK-Gardner Inc., Silver Spring, Maryland, USA) was used. Powders (P): the measurements were carried in the reflectance mode calibrating the equipment previously with black and white mosaics. A plate with a light path of $1.9 \mathrm{~cm}$ in diameter was used. The sample was placed in a weighing bottle $(1.8 \pm 0.3 \mathrm{~g}$ powder) with an external diameter of $2.65 \mathrm{~cm}$. Powder solution (PS) or Roselle extract solutions (RES): the color was assessed in the transmittance mode using a quartz cell (Konica Minolta Sensing Inc., $2 \mathrm{~mm}$ ) of $3 \mathrm{~mL}$ (Salazar-González et al., 2009; Silva et al., 2013). The $L^{*}$ (luminosity: black = 0; white = 100 ), $a^{*}$ (green to red) and $b^{*}$ (yellow to blue) color parameters were measured in the CIELab scale. From these data the purity (color saturation, $\left.C=\left[a^{2}+b^{2}\right]^{1 / 2}\right)$ and hue $\left(H=\tan ^{-1}[b / a]\right)$ were calculated.

\subsubsection{Statistical Analysis}

It was carried out by ANOVA with a level of significance of 0.05 using the software MINITAB ${ }^{\circ}$ version 14.1 (Minitab Inc., 2003). To establish differences between the treatments, a Tukey-Krammer multiple comparison test was used with a $P$ value of 0.05 .

\section{Results and Discussion}

\subsection{Roselle Extracts Concentrates (REC)}

Table 1 shows volumes, weights, and TSSs for RECs used for adding different amounts of carrier agents (GA, $M D, M D: G A)$ at different concentrations $(0,3,5,10 \% \mathrm{w} / \mathrm{w})$. The content of TMAs, TPCs, and ACs of all these RECs is shown in Table 2. The REs used for adding GA, $M D$ and $M D: G A(60: 40)$ had $88.86 \pm 2.82,95.19 \pm 6.84$ and $84.31 \pm 20.93 \mathrm{mg}$ of C-3-G/100 mL, respectively, of TMAs, $591.20 \pm 20.20,709.65 \pm 85.12$, and $788.28 \pm$ $100.19 \mathrm{mg} \mathrm{GAE} / 100 \mathrm{~mL}$, respectively, of TPCs and $251.61 \pm 11.58,239.37 \pm 12.02$ and $235.62 \pm 8.85 \mathrm{mg}$ $T E / 100 \mathrm{~mL}$, respectively, of ACs. All these results are global averages. The TMAs, TPCs and ACs depend strongly in the TSS content (Table 1) due to concentration or elimination of ethanol; therefore, the more concentrated the extract, the more amount of TMAs, TPCs and ACs. Similar results were observed by Cid-Ortega and Guerrero-Beltrán (2020) for extracts of $H$. sabdariffa used for obtaining powders by spray drying.

Table 1. Amount of gums required for adding to $R E C^{l}$ as well as volumes, weights, and total soluble solids of the

\begin{tabular}{|c|c|c|c|c|c|}
\hline Type of gum & Concentration $(\% \mathrm{w} / \mathrm{w})$ & Gum (g) & Extract $(\mathrm{mL})$ & Extract $(\mathrm{g})$ & $T S S^{2}\left({ }^{\circ} \mathrm{Bx}\right)$ \\
\hline \multirow[t]{3}{*}{$G A$} & 3 & $2.28 \pm 0.02$ & $72.50 \pm 0.87$ & $73.90 \pm 0.78$ & $16.69 \pm 0.08$ \\
\hline & 5 & $3.69 \pm 0.16$ & $68.67 \pm 3.22$ & $70.13 \pm 3.02$ & $15.03 \pm 0.21$ \\
\hline & 10 & $8.42 \pm 0.37$ & $74.00 \pm 3.46$ & $75.77 \pm 3.32$ & $15.24 \pm 0.39$ \\
\hline \multirow[t]{3}{*}{$M D$} & 3 & $2.11 \pm 0.17$ & $65.00 \pm 6.08$ & $67.80 \pm 5.37$ & $15.08 \pm 0.48$ \\
\hline & 5 & $3.46 \pm 0.12$ & $63.33 \pm 2.31$ & $65.60 \pm 2.23$ & $14.87 \pm 0.27$ \\
\hline & 10 & $7.72 \pm 0.58$ & $68.00 \pm 5.29$ & $69.43 \pm 5.19$ & $15.02 \pm 0.23$ \\
\hline \multirow[t]{3}{*}{$M D: G A$} & 3 & $2.23 \pm 0.14$ & $70.33 \pm 4.51$ & $72.00 \pm 4.37$ & $16.35 \pm 0.25$ \\
\hline & 5 & $3.60 \pm 0.09$ & $66.67 \pm 1.53$ & $68.27 \pm 1.54$ & $16.16 \pm 0.19$ \\
\hline & 10 & $6.60 \pm 0.83$ & $57.33 \pm 7.51$ & $59.40 \pm 7.51$ & $16.77 \pm 0.84$ \\
\hline
\end{tabular}
$R E C$

${ }^{I} R E C$ : Roselle extracts concentrates. ${ }^{2} T S S$ : Total soluble solids in extracts without gum. RE: Roselle extract. GA: Gum arabic. $M D$ : Maltodextrin. 
Table 2. Antioxidant characteristics of Roselle extracts concentrates $(R E C)^{\mathrm{a}}$

\begin{tabular}{lllll}
\hline Gum & $\begin{array}{l}\text { Concentration } \\
(\% \mathrm{w} / \mathrm{w})\end{array}$ & $\begin{array}{c}T M A^{l} \\
(\mathrm{mg} \mathrm{C}-3-\mathrm{G} / 100 \mathrm{~mL})\end{array}$ & $\begin{array}{c}T P C^{2} \\
(\mathrm{mg} \mathrm{GAE} / 100 \mathrm{~mL})\end{array}$ & $\begin{array}{c}A C^{3} \\
(\mathrm{mg} T E / 100 \mathrm{~mL})\end{array}$ \\
\hline$G A$ & 3 & $87.92 \pm 1.07 \mathrm{~b}$ & $578.07 \pm 9.59 \mathrm{~b}$ & $233.16 \pm 2.59 \mathrm{~b}$ \\
& 5 & $89.98 \pm 1.94 \mathrm{bc}$ & $604.90 \pm 19.96 \mathrm{bg}$ & $229.58 \pm 2.98 \mathrm{cb}$ \\
& 10 & $88.67 \pm 4.42 \mathrm{~b}$ & $590.62 \pm 21.55 \mathrm{~b}$ & $255.37 \pm 2.70 \mathrm{~d}$ \\
$M D$ & 3 & $97.36 \pm 5.11 \mathrm{cde}$ & $788.83 \pm 44.97 \mathrm{cef}$ & $253.26 \pm 1.24 \mathrm{ad}$ \\
& 5 & $99.22 \pm 5.18 \mathrm{de}$ & $731.22 \pm 34.97 \mathrm{ac}$ & $264.39 \pm 1.67 \mathrm{e}$ \\
& 10 & $89.01 \pm 5.92 \mathrm{~b}$ & $608.91 \pm 33.62 \mathrm{bd}$ & $237.18 \pm 1.65 \mathrm{bf}$ \\
& 3 & $57.33 \pm 3.61 \mathrm{a}$ & $671.20 \pm 46.01 \mathrm{adg}$ & $244.57 \pm 10.20 \mathrm{f}$ \\
& 5 & $90.53 \pm 1.99 \mathrm{bc}$ & $860.22 \pm 36.60 \mathrm{ef}$ & $231.95 \pm 2.64 \mathrm{~b}$ \\
& 10 & $105.06 \pm 5.94 \mathrm{e}$ & $833.43 \pm 74.61 \mathrm{f}$ & $230.35 \pm 3.14 \mathrm{~b}$ \\
\hline
\end{tabular}

${ }^{\mathrm{a}}$ Different letter within values in the same column indicate significant differences $(\mathrm{p} \leq 0.05) .{ }^{I}$ TMAs: total monomeric anthocyanins (cyanidin-3-glucoside equivalents). ${ }^{2} T P C s$ : total phenolic compounds (gallic acid equivalents). ${ }^{3} A C$ : antioxidant capacity (Trolox equivalents). RE: Roselle extracts. GA: gum Arabic. $M D$ : maltodextrin.

\subsection{Roselle Extracts Concentrates-gums (RECG)}

\subsubsection{Physical Properties}

Table 3 shows the content of total soluble solids, density and viscosity for all RECG.

Total soluble solids (TSS). The TSS content (as global averages) for the RECG added with GA, MD, and MD:GA $(60: 40)(19.40 \pm 2.43,20.01 \pm 2.57$, and $21.10 \pm 2.79 \%$, respectively) did not show any significant difference (p > $0.05)$. The REC had the lower amount of TSS content $(16.14 \pm 0.74 \%)$ since no gum was added. Regarding the concentration of gums, the TSS content increased as the concentration of gum increased in the RECs: $16.14 \pm$ $0.74,17.73 \pm 0.65,19.29 \pm 0.70$ and $23.49 \pm 1.00 \%$ for $0,3,5$ and $10 \%$, respectively, global averages. Comparable results were observed by Cid-Ortega and Guerrero-Beltrán (2020) for the RECG used for obtaining powders by spray drying.

Table 3. Physical characteristics of Roselle extracts concentrates-gums $(R E C G)^{\mathrm{a}}$

\begin{tabular}{lllll}
\hline Gum & Concentration $(\% \mathrm{w} / \mathrm{w})$ & $T S S\left({ }^{\circ} \mathrm{Bx}\right)$ & Density $\left(\mathrm{g} / \mathrm{cm}^{3}\right)$ & Viscosity $^{1}(\mathrm{mPa})$ \\
\hline$G A$ & 3 & $17.03 \pm 0.14 \mathrm{abd}$ & $1.05 \pm 0.01 \mathrm{ab}$ & $2.30 \pm 0.04 \mathrm{~b}$ \\
& 5 & $18.69 \pm 0.30 \mathrm{beg}$ & $1.05 \pm 0.01 \mathrm{ab}$ & $3.06 \pm 0.04 \mathrm{c}$ \\
& 10 & $22.47 \pm 0.33 \mathrm{cf}$ & $1.06 \pm 0.01 \mathrm{abc}$ & $7.19 \pm 0.11 \mathrm{~d}$ \\
$M D$ & 3 & $17.67 \pm 0.31 \mathrm{dj}$ & $1.06 \pm 0.01 \mathrm{abc}$ & $1.88 \pm 0.03 \mathrm{a}$ \\
& 5 & $19.05 \pm 0.36 \mathrm{eg}$ & $1.07 \pm 0.01 \mathrm{bced}$ & $1.97 \pm 0.03 \mathrm{a}$ \\
& 10 & $23.32 \pm 0.26 \mathrm{f}$ & $1.08 \pm 0.01 \mathrm{~cd}$ & $2.60 \pm 0.06 \mathrm{~b}$ \\
$M D: G A$ & 3 & $18.48 \pm 0.12 \mathrm{gj}$ & $1.04 \pm 0.01 \mathrm{a}$ & $2.12 \pm 0.03 \mathrm{~b}$ \\
& 5 & $20.14 \pm 0.07 \mathrm{~h}$ & $1.05 \pm 0.01 \mathrm{ae}$ & $2.50 \pm 0.04 \mathrm{ib}$ \\
& 10 & $24.69 \pm 0.38 \mathrm{i}$ & $1.08 \pm 0.01 \mathrm{~d}$ & $3.98 \pm 0.04 \mathrm{c}$ \\
\hline
\end{tabular}

${ }^{a}$ Values with different letters within the same column have significant differences $(\mathrm{p} \leq 0.05) .{ }^{1}$ Viscosity at $25^{\circ} \mathrm{C}$.

Density. The densities of the RECG (Table 3) added with $G A, M D$ and $M D: G A(60: 40)$ were $1.05 \pm 0.01,1.07 \pm$ 0.01 , and $1.06 \pm 0.02 \mathrm{~g} / \mathrm{mL}$, respectively, as global averages; however, no significant differences were observed ( $\mathrm{p}>0.05$ ). The RECG added with $M D$ and $M D: G A$ (60:40) showed higher densities. About the concentration of gums, RECG added with $3 \%$ of gums had lower density than the extracts with 5 or $10 \%$ of gum. Janiszewska and Witrowa-Rajchert (2009) carried out a study to explore the efficiency of the microencapsulation of rosemary aroma using maltodextrin (25 and 30\%), gum arabic (30\%) and maltodextrin:gum arabic in a 3:1 ratio (30\%). The extracts with gum had densities of $1.04,1.05,1.03$ and $1.05 \mathrm{~g} / \mathrm{mL}$ for $25 \%$ of maltodextrin, $30 \%$ of maltodextrin, $30 \%$ of gum arabic and $30 \%$ of the mixture maltodextrin:gum arabic, respectively.

Viscosity. The viscosity of the RECG (Table 3) added with $G A$ had the highest viscosities $(4.18 \pm 2.28 \mathrm{mPa} . \mathrm{s})$ than the extracts with $M D(2.15 \pm 0.34 \mathrm{mPa} . \mathrm{s})$ or a blend of $M D: G A(2.87 \pm 0.04 \mathrm{mPa} . \mathrm{s}$, global averages. Regarding the concentration of gum, the RECG with $10 \%$ had the highest viscosity compared with 0,3 and 5\% of gums $(4.58 \pm 2.04,1.72 \pm 0.03,2.10 \pm 0.19$ and $2.50 \pm 0.47 \mathrm{mPa} \mathrm{s}$, respectively, global averages $)$. 
Gharsallaoui et al., 2007 had reported that $G A$ showed excellent emulsifying properties due to the fact that its structure contains a fraction of protein (approximately $2 \%$ ), which gives this property.

\subsection{Roselle Powders (RPs)}

\subsubsection{Granulometry of Roselle Calyces Powder $(R C P)$}

Figure 1 shows the granulometric distribution of the Roselle calyces powder used for obtaining the Roselle extracts. The average diameter $\left(\mathrm{d}_{50}\right)$ was $231.50 \pm 18.40 \mathrm{~mm}$ with a moisture content of $6.45 \pm 0.43 \%$.

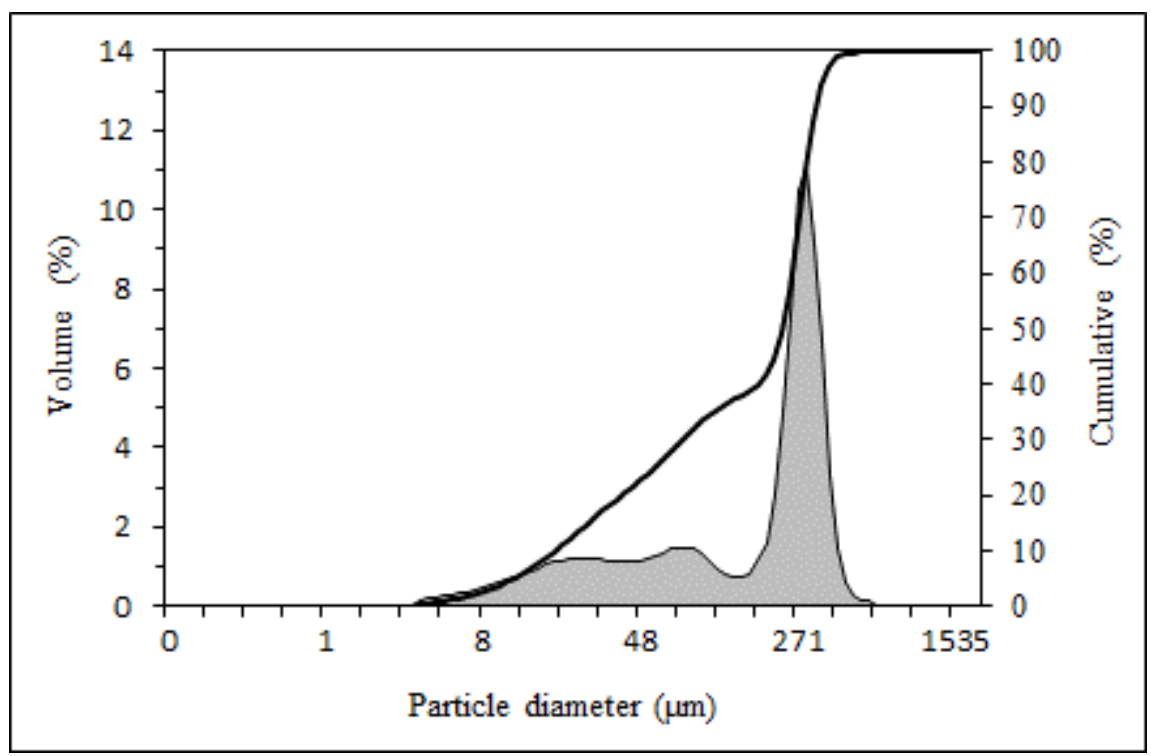

Figure 1. Particle size distribution of Roselle calyces powders

\subsubsection{Yields of Powders}

The yields global averages of powders of $R E$ and those added with $G A, M D$ and $M D: G A$ (60:40) were of $85.89 \pm$ $7.49,86.93 \pm 2.58,90.85 \pm 2.51$ and $86.83 \pm 3.25 \%$, respectively. The yields global averages for powders with 0 , 3,5 and $10 \%$ of gum were $85.89 \pm 7.49,86.68 \pm 3.73,87.97 \pm 3.47$ and $89.96 \pm 1.82 \%$ for $0,3,5$ and $10 \%$ of gum, respectively.

\subsubsection{Physicochemical Characteristics}

Table 4 shows the effect of gums on the physicochemical properties of Roselle powders.

Moisture content. The type of gum did not affect significantly $(\mathrm{p}>0.05)$ the moisture content of powders: $8.62 \pm$ $0.59,8.05 \pm 2.61,8.01 \pm 1.13$, and $8.39 \pm 1.82 \%$ (global averages) of $R E, G A, M D$, and $M D: G A(60: 40$ ), respectively. However, differences in the moisture content were observed as the gum concentration increased: $8.62 \pm 0.59,10.09 \pm 1.19,7.93 \pm 0.59$, and $6.44 \pm 1.46 \%$ for $0,3,5$, and $10 \%$ of gum, respectively (global average). Similar behavior was reported by Farimin and Nordin (2009) when obtaining spray-dried powders from Roselle:pineapple juice (1:1) encapsulated with maltodextrin. They found that the moisture content of powders decreased as the maltodextrin concentration increased: $1.84 \pm 0.30,1.53 \pm 0.14,1.40 \pm 0.09 \%$ for 3,5 , and $10 \%$ of gum, respectively. Similar results were reported by Fazaeli et al. (2012) when increasing the concentration of maltodextrin (DE 9) $(8,12$ and 16\%) in encapsulated blackberry juice by spry-drying. The moisture content of their powders ranged 1.5-2.0\% using a flow rate of $800 \mathrm{~L} / \mathrm{h}$ and an air entering temperature of $150^{\circ} \mathrm{C}$. On the other hand, Goula and Adamopoulos (2008) reported an increase in moisture content in encapsulated powders of tomato pulp when increasing the concentration of maltodextrin in different proportions of tomato pulp:maltodextrin (4:1,1:1 and 1:4). They reported moisture contents in the range $2.91-12.41 \%$. 
Table 4. Effect of gum types and concentrations on the physico-chemical properties of powders obtained by lyophilization $^{\mathrm{a}}$

\begin{tabular}{lllllll}
\hline $\begin{array}{l}\text { Gum } \\
\text { type }\end{array}$ & $\begin{array}{l}\text { Gum } \\
(\% \mathrm{w} / \mathrm{w})\end{array}$ & $\begin{array}{l}\text { Moisture } \\
(\%)\end{array}$ & $\begin{array}{l}a_{w} \\
\left(\text { at } 25.1 \pm 0.06^{\circ} \mathrm{C}\right)\end{array}$ & $\begin{array}{l}\text { Average diameter } \\
\mathrm{d}_{50}(\mu \mathrm{m})\end{array}$ & $\begin{array}{l}\text { Bulk density } \\
\left(\mathrm{g} / \mathrm{cm}^{3}\right)\end{array}$ & $\begin{array}{l}\text { Tap density } \\
\left(\mathrm{g} / \mathrm{cm}^{3}\right)\end{array}$ \\
\hline$R E C$ & 0 & $8.62 \pm 0.59 \mathrm{ah}$ & $0.277 \pm 0.023 \mathrm{ac}$ & $139.50 \pm 25.55 \mathrm{a}$ & $0.670 \pm 0.017 \mathrm{a}$ & $0.800 \pm 0.030 \mathrm{ac}$ \\
$G A$ & 3 & $11.20 \pm 0.43 \mathrm{~b}$ & $0.237 \pm 0.015 \mathrm{abc}$ & $57.13 \pm 5.46 \mathrm{bc}$ & $0.530 \pm 0.030 \mathrm{~b}$ & $0.673 \pm 0.045 \mathrm{bde}$ \\
& 5 & $7.70 \pm 0.22 \mathrm{ac}$ & $0.287 \pm 0.031 \mathrm{a}$ & $46.84 \pm 15.72 \mathrm{~b}$ & $0.550 \pm 0.017 \mathrm{~b}$ & $0.670 \pm 0.050 \mathrm{bde}$ \\
& 10 & $5.27 \pm 0.57 \mathrm{dj}$ & $0.250 \pm 0.020 \mathrm{ad}$ & $80.83 \pm 8.28 \mathrm{c}$ & $0.607 \pm 0.040 \mathrm{abc}$ & $0.797 \pm 0.038 \mathrm{c}$ \\
$M D$ & 3 & $8.67 \pm 0.57 \mathrm{ae}$ & $0.197 \pm 0.021 \mathrm{bd}$ & $43.65 \pm 1.57 \mathrm{~b}$ & $0.530 \pm 0.044 \mathrm{~b}$ & $0.627 \pm 0.064 \mathrm{bd}$ \\
& 5 & $7.63 \pm 0.72 \mathrm{af}$ & $0.220 \pm 0.000 \mathrm{~cd}$ & $44.63 \pm 1.26 \mathrm{~b}$ & $0.560 \pm 0.000 \mathrm{bc}$ & $0.717 \pm 0.006 \mathrm{abc}$ \\
& 10 & $7.72 \pm 1.80 \mathrm{afg}$ & $0.277 \pm 0.038 \mathrm{ac}$ & $40.51 \pm 2.09 \mathrm{~b}$ & $0.587 \pm 0.046 \mathrm{abc}$ & $0.707 \pm 0.032 \mathrm{abc}$ \\
$M D: G A$ & 3 & $10.39 \pm 0.43 \mathrm{beh}$ & $0.197 \pm 0.060 \mathrm{bd}$ & $58.40 \pm 14.24 \mathrm{bc}$ & $0.640 \pm 0.036 \mathrm{ac}$ & $0.730 \pm 0.010 \mathrm{acde}$ \\
& 5 & $8.46 \pm 0.46 \mathrm{ahí}$ & $0.217 \pm 0.015 \mathrm{~cd}$ & $71.54 \pm 11.08 \mathrm{bc}$ & $0.547 \pm 0.012 \mathrm{~b}$ & $0.663 \pm 0.021 \mathrm{be}$ \\
& 10 & $6.32 \pm 0.64 \mathrm{cfij}$ & $0.247 \pm 0.025 \mathrm{ad}$ & $71.98 \pm 6.34 \mathrm{bc}$ & $0.590 \pm 0.010 \mathrm{ab}$ & $0.747 \pm 0.025 \mathrm{ace}$ \\
\hline
\end{tabular}

${ }^{\mathrm{a}}$ Values with different letters in each column have significant differences $(\mathrm{p} \leq 0.05)$.

Water activity $\left(a_{w}\right)$. The results of $a_{w}$ are shown in Table 4. Regarding the type of gum, significant differences (p $<0.05)$ were observed between the REC $(0.277 \pm 0.023)$ and $M D: G A(60: 40)(0.220 \pm 0.026)$ powders as well as between the $G A(0.258 \pm 0.030)$ and $M D(0.231 \pm 0.042)$ powders (global averages). About the concentration of gum, powders with $3 \%$ of gum had lower $a_{w}(0.210 \pm 0.024$, global average). Powders with 0,5 and $10 \%$ of gum had $a_{w}$ s of $0.277 \pm 0.0230,0.241 \pm 0.015$ and $258 \pm 0.029$, respectively (global averages). The former information differs from that reported by Farimin and Nordin (2009); they reported a decrease in $a_{w}$ when increasing the concentration of maltodextrin ( $a_{w} \mathrm{~s}$ of $0.27,0.22$ and 0.21 for 3,5 and $10 \%$, respectively) in spray dried powders of a mixture of Roselle extract:pineapple juice (1:1). Comunian et al. (2011) observed no significant differences in $a_{w}$ s of powders of $5 \%$ chlorophyllide solution obtained with gum arabic $(0.31 \pm 0.10)$, maltodextrin $(0.31 \pm 0.14)$, and soy protein $(0.28 \pm 0.04)$ by spray drying.

Average diameter $\left(d_{50}\right)$. The $d_{50}$ values of Roselle powders are shown in Table 4. The gum type showed significant differences $(\mathrm{p} \leq 0.05)$ among $d_{50}$ values of $M D(42.93 \pm 2.36 \mu \mathrm{m}), G A(61.60 \pm 17.72 \mu \mathrm{m})$ and $M D: G A(60: 40)(67.31 \pm 11.67 \mu \mathrm{m})$ powders, all global averages. The powder of $R E C$ showed the highest $d_{50}$ value $(139.50 \pm 25.55 \mu \mathrm{m})$. Figure 2 shows some examples of the particle size distribution of powders. All powders had a bimodal behavior. The powders showed heterogeneous particles; therefore, large particles were shaped through the process of agglomeration (Tonon et al., 2011). Comunian et al. (2011) reported a bimodal particle size distribution in powders, obtained from a 5\% chlorophyllide solution, with $d_{50}$ values between 11.2 to $19.04 \mu \mathrm{m}$. The powders were obtained as already mentioned above. On the other hand, Janiszewska and Witrowa-Rajchert (2009) reported $d_{50}$ values of 55 and $29 \mu \mathrm{m}$ for powders obtained with $25 \%$ of maltodextrin or $30 \%$ of gum arabic for encapsulated rosemary aromas obtained by spray drying.

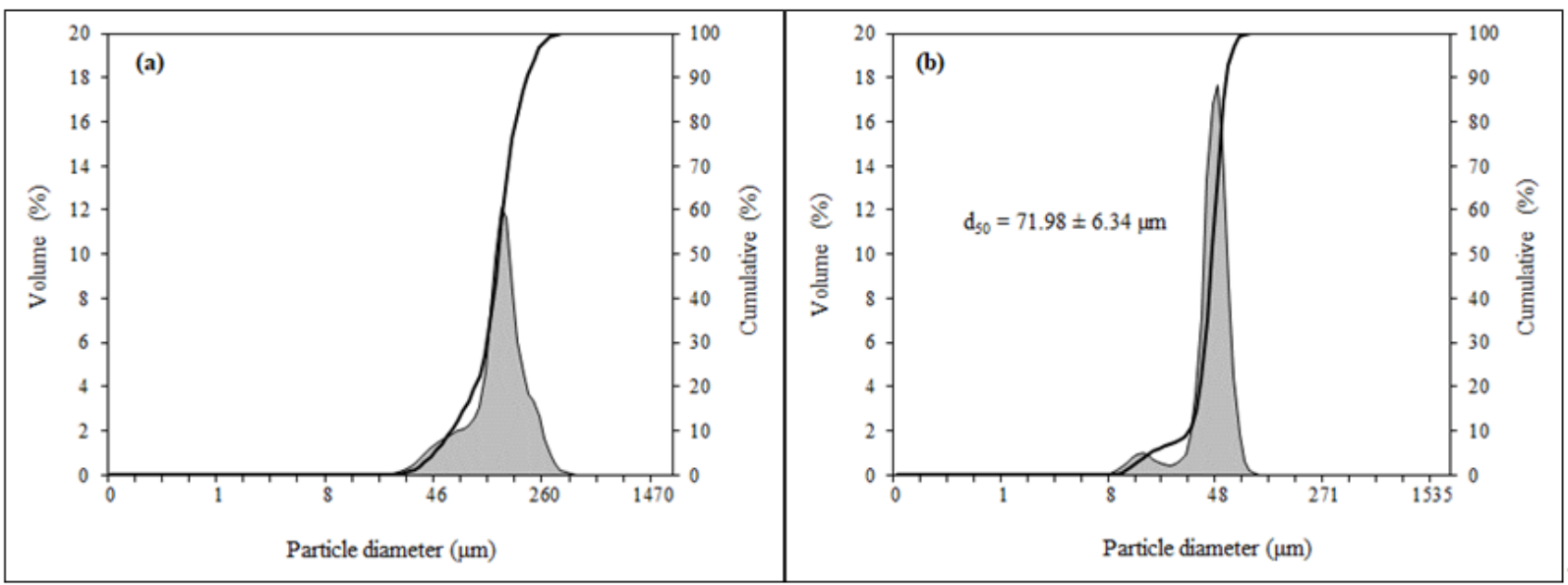



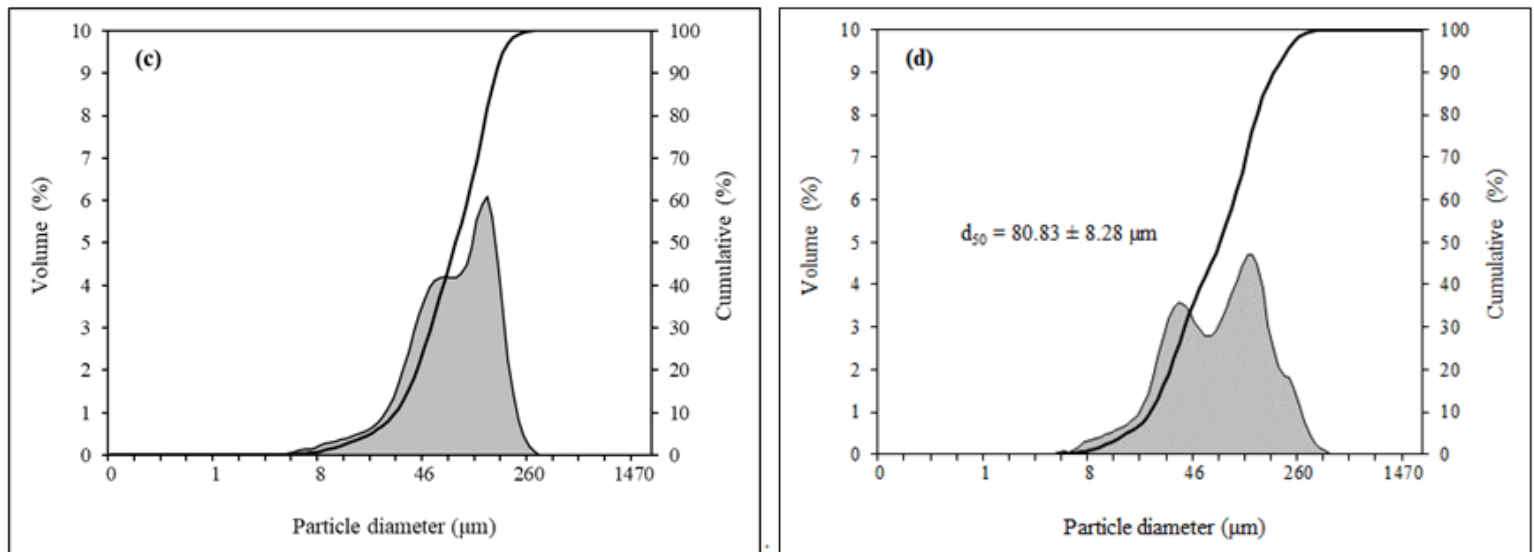

Figure 2. Particle size distribution of lyophilized powders obtained with REC (a); 3\% MD (b); $10 \%$ GA (c), and $10 \% M D: G A(60: 40)(\mathrm{d})$

Bulk density. The bulk or apparent density of the Roselle powders is shown in Table 4. According to the type of gum, the powder of $R E C$ had the highest density $(0.670 \pm 0.017 \mathrm{~g} / \mathrm{mL})$ in comparison with the densities of $G A$ $(0.562 \pm 0.044 \mathrm{~g} / \mathrm{mL}), M D(0.559 \pm 0.040 \mathrm{~g} / \mathrm{mL})$ and $M D: G A(60: 40)(0.592 \pm 0.045 \mathrm{~g} / \mathrm{mL})$ powders (global averages for all powders). About the gum concentration, the REC powder had the highest density compared with the densities of $G A(0.567 \pm 0.064 \mathrm{~g} / \mathrm{mL}), M D(0.552 \pm 0.012 \mathrm{~g} / \mathrm{mL})$ and $M D: G A(60: 40)(0.594 \pm 0.033 \mathrm{~g} / \mathrm{mL})$ powders. Different results were observed by Fazaeli et al. (2012); they reported decreasing bulk densities (from 0.55 to $0.35 \mathrm{~g} / \mathrm{mL}$ ) when increasing the concentration of maltodextrin (DE 9) $(8,12$, and 16\%) in powders of blackberry juice obtained by spray drying at different temperatures $\left(110,130\right.$, and $\left.150^{\circ} \mathrm{C}\right)$. Tonon et al. (2011) pointed out that the smaller the particle size, the greater the apparent density in powders of açaí (Euterpe oleracea) juice obtained by spray drying using gum arabic and maltodextrin (10 and $20 \mathrm{DE})$. Results obtained in this work could be due to the drying conditions and types and concentrations of gums.

Tap density. Significant differences were observed $(\mathrm{p} \leq 0.05)$ between the tap density of $R E C(0.800 \pm 0.030$ $\mathrm{g} / \mathrm{mL})$ and $M D(0.683 \pm 0.056 \mathrm{~g} / \mathrm{mL}$, global average) powders. No significant differences $(\mathrm{p}>0.05)$ were observed within densities of $G A(0.713 \pm 0.074 \mathrm{~g} / \mathrm{mL}$, global average) and $M D: G A(60: 40)(0.713 \pm 0.042 \mathrm{~g} / \mathrm{mL}$, global average) powders. In the case of the gums concentration, the tap densities were higher for the REC $(0.800$ $\pm 0.030 \mathrm{~g} / \mathrm{mL})$ and $10 \%$ of gum $(0.750 \pm 0.048 \mathrm{~g} / \mathrm{mL}$, global average) powders in comparison with powders with $3(0.677 \pm 0.060 \mathrm{~g} / \mathrm{mL}$, global average $)$ and $5 \%(0.683 \pm 0.037 \mathrm{~g} / \mathrm{mL}$, global average $)$ of gums.

\subsubsection{Color of Powders}

The color properties of the Roselle powders are shown in Table 5. All powders had a pale pink color.

Lightness $\left(L^{*}\right)$ : The REC powder had the lowest lightness $(28.12 \pm 0.48)$ (therefore, the darkest one) in comparison with the $G A(36.39 \pm 2.71$, global average), $M D(36.40 \pm 2.94$, global average) and $M D: G A(60: 40)$ $(35.30 \pm 4.66$, global average) powders. It was observed that, increasing the concentration of gum, powders with gum became clearer: $33.24 \pm 2.58,35.30 \pm 1.22$ and $39.56 \pm 2.65$ for 3,5 and $10 \%$ of gum, respectively (global averages). The lowest $L^{*}$ value $(29.90 \pm 0.060)$ for powders with gum was observed in the MD:GA (60:40) powder at a concentration of $3 \%$ of gum. Ersus and Yurdagel (2007) reported an increase in lightness $\left(L^{*}\right)$ of microencapsulated anthocyanin pigments from Daucus carota L. obtained by spray drying when decreasing the dextrose equivalents $(10,20-23,28-31 \mathrm{DE})$ of maltodextrin. They also pointed out that the hue was higher for the powders obtained with maltodextrin of 28-31 DE. The authors concluded that the color of the powders became paler when increasing the DE of maltodextrin. Idham et al. (2012) reported $L^{*}, a^{*}$, and $b^{*}$ color values for anthocyanins from Roselle extracts encapsulated by spray drying using the same gums as in this study. They reported values of $39.3,43.1$, and -0.8 for $M D, 45.9,34.8$, and -4.3 for $M D: G A(60: 40)$, and $44.9,30.3$, and -6.3 for $G A$ for $L^{*}, a^{*}$, and $b^{*}$ color parameters, respectively. These values are different than those obtained in this study.

Green-red color $\left(a^{*}\right)$ : The REC powder had the lowest red coloration $\left(a^{*}=30.11 \pm 1.23\right)$ than powders with $G A$ (38.02 \pm 1.77 , global average), $M D$ (37.88 \pm 0.40 , global average) and $M D: G A$ (60:40) (37.39 \pm 1.94 , global average). The same behavior was observed for powders with 3,5 and $10 \%$ gum: $37.18 \pm 1.81,38.84 \pm 0.66$ and $37.28 \pm 1.29$, respectively (global averages). The highest red coloration $(39.23 \pm 0.82)$ was observed in the 
powder with $5 \%$ of $G A$.

Yellow-blue color $\left(b^{*}\right)$ : No significant differences were observed $(\mathrm{p}>0.05)$ among the type of gum in all powders: REC (11.59 \pm 0.90 , global average), $G A$ (11.17 \pm 1.81 , global average), $M D(11.78 \pm 1.06$ and global average) and $M D: G A(60: 40)(12.71 \pm 2.24$, global average) about the yellow color. There were no significant differences ( $\mathrm{p}>0.05)$ observed about yellowness within the powder of $R E C\left(b^{*}=11.59 \pm 0.90\right)$ and the other powders: 3,5 and $10 \%$ gum showed $b^{*}$ values of $13.29 \pm 1.36,12.50 \pm 0.54$ and $9.87 \pm 1.19$, respectively (global averages); however, a decrease in $b^{*}$ values were observed when increasing the concentration of gums.

Table 5. Effect of types and concentrations of gums on the color properties of Roselle powders obtained by lyophilization $^{\text {a }}$

\begin{tabular}{lllllll}
\hline $\begin{array}{l}\text { Gum } \\
\text { type }\end{array}$ & $\begin{array}{l}\text { Gum } \\
(\% \mathrm{w} / \mathrm{w})\end{array}$ & \multicolumn{1}{c}{$L^{*}$} & $a^{*}$ & $b^{*}$ & Hue $\left(H^{\circ}\right)$ & Purity $(C)$ \\
\hline \multicolumn{7}{c}{} \\
\hline$R E C$ & 0 & $28.12 \pm 0.48 \mathrm{ad}$ & $30.11 \pm 1.23 \mathrm{a}$ & $11.59 \pm 0.90 \mathrm{ad}$ & $21.03 \pm 1.06 \mathrm{a}$ & $32.27 \pm 1.41 \mathrm{a}$ \\
$G A$ & 3 & $35.37 \pm 0.65 \mathrm{bc}$ & $38.97 \pm 0.69 \mathrm{~b}$ & $12.37 \pm 0.56 \mathrm{a}$ & $17.61 \pm 0.62 \mathrm{bd}$ & $40.89 \pm 0.77 \mathrm{~b}$ \\
& 5 & $33.98 \pm 0.68 \mathrm{bf}$ & $39.23 \pm 0.82 \mathrm{~b}$ & $12.32 \pm 0.07 \mathrm{a}$ & $17.44 \pm 0.36 \mathrm{bd}$ & $41.12 \pm 0.78 \mathrm{~b}$ \\
& 10 & $39.83 \pm 0.58 \mathrm{ce}$ & $35.87 \pm 0.96 \mathrm{~cd}$ & $8.80 \pm 0.52 \mathrm{~b}$ & $13.78 \pm 0.48 \mathrm{cf}$ & $36.94 \pm 1.05 \mathrm{c}$ \\
$M D$ & 3 & $34.45 \pm 0.45 \mathrm{bf}$ & $37.56 \pm 0.35 \mathrm{bc}$ & $12.45 \pm 0.38 \mathrm{a}$ & $18.34 \pm 0.66 \mathrm{bd}$ & $39.57 \pm 0.25 \mathrm{bd}$ \\
& 5 & $36.45 \pm 0.75 \mathrm{bce}$ & $38.19 \pm 0.25 \mathrm{~b}$ & $12.15 \pm 0.42 \mathrm{a}$ & $17.65 \pm 0.63 \mathrm{bd}$ & $40.08 \pm 0.21 \mathrm{bd}$ \\
& 10 & $38.29 \pm 4.76 \mathrm{bce}$ & $37.90 \pm 0.39 \mathrm{bc}$ & $10.74 \pm 1.28 \mathrm{ab}$ & $15.82 \pm 1.88 \mathrm{bcf}$ & $39.40 \pm 0.36 \mathrm{bd}$ \\
$M D: G A$ & 3 & $29.90 \pm 0.60 \mathrm{df}$ & $35.01 \pm 0.64 \mathrm{~d}$ & $15.03 \pm 0.28 \mathrm{c}$ & $23.24 \pm 0.10 \mathrm{a}$ & $38.10 \pm 0.69 \mathrm{dc}$ \\
& 5 & $35.47 \pm 0.59 \mathrm{~b}$ & $39.09 \pm 0.29 \mathrm{~b}$ & $13.03 \pm 0.57 \mathrm{a}$ & $18.44 \pm 0.85 \mathrm{~d}$ & $41.21 \pm 0.19 \mathrm{~b}$ \\
& 10 & $40.54 \pm 1.10 \mathrm{e}$ & $38.08 \pm 1.05 \mathrm{~b}$ & $10.06 \pm 0.91 \mathrm{db}$ & $14.78 \pm 0.93 \mathrm{f}$ & $39.40 \pm 1.23 \mathrm{~b}$ \\
& \multicolumn{5}{c}{ Powder in solution } & \\
$R E C$ & 0 & $71.26 \pm 0.16 \mathrm{a}$ & $24.69 \pm 0.09 \mathrm{a}$ & $12.56 \pm 0.16 \mathrm{a}$ & $26.99 \pm 0.15 \mathrm{a}$ & $27.71 \pm 0.13 \mathrm{a}$ \\
$G A$ & 3 & $73.37 \pm 0.16 \mathrm{~b}$ & $29.65 \pm 0.40 \mathrm{~b}$ & $12.84 \pm 0.42 \mathrm{a}$ & $23.41 \pm 0.45 \mathrm{~b}$ & $32.31 \pm 0.52 \mathrm{~b}$ \\
& 5 & $75.83 \pm 0.13 \mathrm{ce}$ & $26.65 \pm 0.27 \mathrm{c}$ & $11.09 \pm 0.13 \mathrm{~b}$ & $22.59 \pm 0.08 \mathrm{bd}$ & $28.86 \pm 0.29 \mathrm{a}$ \\
& 10 & $79.89 \pm 0.39 \mathrm{~d}$ & $20.33 \pm 0.24 \mathrm{de}$ & $8.80 \pm 0.16 \mathrm{c}$ & $23.41 \pm 0.50 \mathrm{~b}$ & $22.16 \pm 0.21 \mathrm{ce}$ \\
$M D$ & 3 & $71.81 \pm 0.74 \mathrm{a}$ & $29.90 \pm 0.58 \mathrm{~b}$ & $11.01 \pm 0.30 \mathrm{~b}$ & $20.22 \pm 0.46 \mathrm{c}$ & $31.86 \pm 0.60 \mathrm{~b}$ \\
& 5 & $74.93 \pm 0.77 \mathrm{c}$ & $26.75 \pm 0.81 \mathrm{cf}$ & $9.81 \pm 0.24 \mathrm{~d}$ & $20.15 \pm 0.18 \mathrm{c}$ & $28.50 \pm 0.84 \mathrm{a}$ \\
& 10 & $80.70 \pm 0.85 \mathrm{~d}$ & $20.63 \pm 1.20 \mathrm{deg}$ & $7.27 \pm 0.33 \mathrm{e}$ & $19.42 \pm 0.57 \mathrm{c}$ & $21.87 \pm 1.23 \mathrm{c}$ \\
$M D: G A$ & 3 & $76.69 \pm 0.68 \mathrm{e}$ & $21.74 \pm 0.31 \mathrm{eg}$ & $11.67 \pm 0.20 \mathrm{~b}$ & $28.23 \pm 0.46 \mathrm{a}$ & $24.67 \pm 0.30 \mathrm{~d}$ \\
& 5 & $75.49 \pm 0.36 \mathrm{ce}$ & $26.98 \pm 0.21 \mathrm{f}$ & $11.33 \pm 0.26 \mathrm{~b}$ & $22.78 \pm 0.12 \mathrm{bd}$ & $29.26 \pm 0.20 \mathrm{a}$ \\
& 10 & $79.39 \pm 0.57 \mathrm{~d}$ & $21.95 \pm 0.41 \mathrm{~g}$ & $8.81 \pm 0.36 \mathrm{c}$ & $21.87 \pm 1.03 \mathrm{~d}$ & $23.65 \pm 0.34 \mathrm{de}$ \\
\hline
\end{tabular}

${ }^{a}$ The values represent the mean \pm standard deviation $(n=3)$, values with different letters in each column show significant differences $(\mathrm{p} \leq 0.05)$.

Hue $\left(H^{\circ}\right)$ : Regarding the hue values of powders with different types of gums (Table 5), the values of hue of powders with gum showed significant differences $(\mathrm{p} \leq 0.05)$ in comparison with the $R E C$ powder $\left(21.03 \pm 1.06^{\circ}\right)$. No differences were observed within hue values of $M D$ (17.27 $\pm 1.54^{\circ}$, global average) and $M D: G A$ (60:40) $\left(18.82 \pm 3.73^{\circ}\right.$, global average) powders. In relation to the concentration of gum, a decrease in hue values was observed when increasing the gum concentration: $21.03 \pm 1.06,19.73 \pm 2.69,17.84 \pm 0.72$ and $14.79 \pm 1.39^{\circ}$ (global averages) for $0,3,5$, and $10 \%$ of gums, respectively; therefore, according to the CIELab* color space (HunterLab, 1991), the reddish hue was decreased.

Purity $(C)$ : The $R E C$ powder had the lowest purity $(32.27 \pm 1.41)$ than that of powders with $G A, M D$ and $M D: G A$ (60:40): $39.65 \pm 2.17,39.69 \pm 0.39$ and $39.57 \pm 1.53$, respectively (global average). Regarding the concentration of gum, the REC powder showed the lowest purity $(\mathrm{p} \leq 0.05)$ than that of powders with 3,5 and $10 \%$ of gum: $39.52 \pm 1.32,40.80 \pm 0.68$ and $38.58 \pm 1.48$, respectively (global average). The value of purity or Chroma is proportional to the amount of color or hue. This could be observed by correlating the color data of the $a^{*}$ color parameter and purity of all powders (Figure 3). Salazar-González et al. (2009) obtained microencapsulated powders of Roselle extracts and mesquite gum at different concentrations $(1,2,3,4$, and 5\% $w / v)$. They reported average values, on the Hunter scale, of $40.3 \pm 0.71,31.93 \pm 0.29,0.28 \pm 0.00$, and $33.19 \pm$ 0.3 for $L, a, H$, and $C$, respectively. The authors concluded that the gum concentration did not have a significant effect on the color parameters. 


\subsubsection{Color of Solutions of Powders}

The color characteristics for the reconstituted Roselle powders are shown in Table 5. All solutions had a transparent red-purple color.

Lightness $\left(L^{*}\right)$ : It can be seen that, increasing the concentration of gum, the solutions were clearer: $71.26 \pm 0.16$, $73.96 \pm 2.22,75.42 \pm 0.56$ and $79.99 \pm 0.79$ for $0,3,5$ and $10 \%$ of gum, respectively (global averages). The solutions of powers of $R E C$ and 3\% MD were the darkest. Salazar-González et al. (2009) reported similar values to this research for the $L^{*}$ and $a^{*}$ color parameters of solutions from reconstituted powders $(100 \mathrm{mg} / 7.5 \mathrm{~mL}$ distilled water) of Roselle extracts added with mesquite gum at different concentrations $(1,2,3,4$ and $5 \% \mathrm{w} / \mathrm{v})$. Then, the type of gum barely affected lightness; however, as the concentration of gum increases, the solutions became lighter; therefore, its purity decreases (Chroma) and consequently, its red coloration.

Green-red color $\left(a^{*}\right)$ : The red color of the solutions did not show significant differences $(\mathrm{p}>0.05)$ about the type of gum; however, the solutions with $10 \%$ of gum had the lower red color $(20.97 \pm 0.98$, global average) than powder solutions with 0,3 and $5 \%$ of gum $(24.69 \pm 0.86,27.10 \pm 4.04$ and $26.79 \pm 0.46$, respectively, global averages).

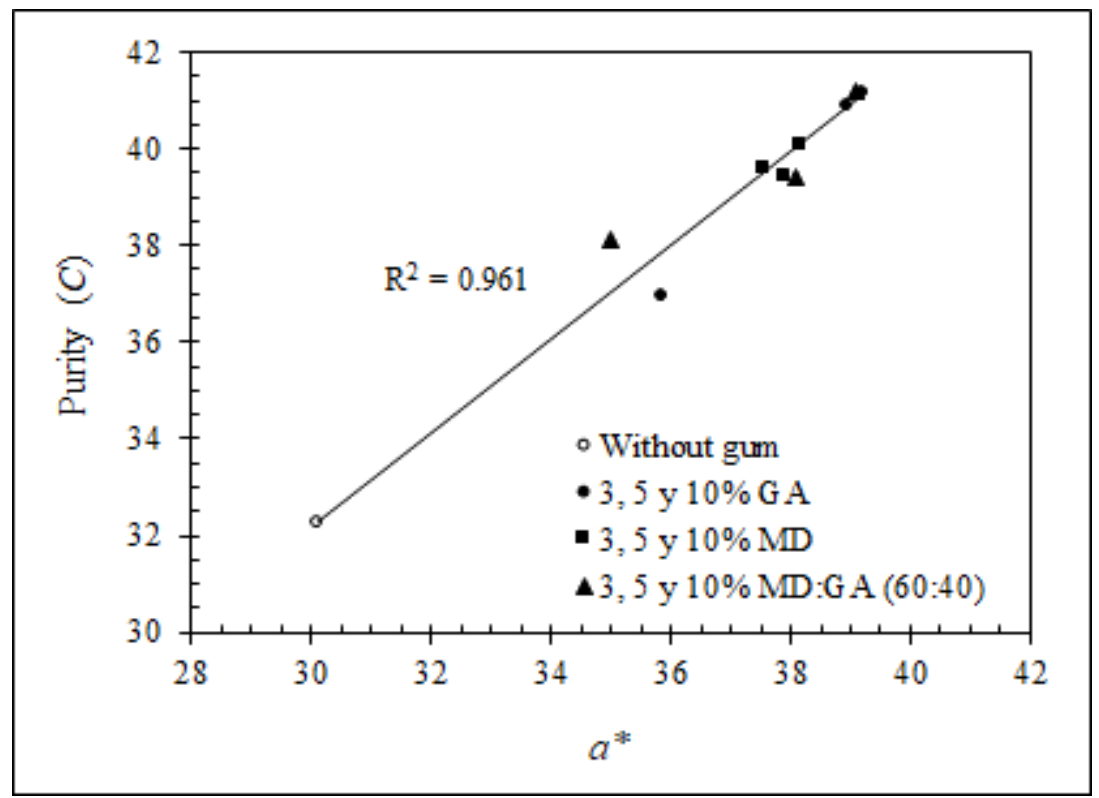

Figure 3. Correlation between the purity and the $a^{*}$ color parameter of microencapsulated powders obtained by lyophilization with gum arabic $(G A)$, maltodextrin $(M D)$ and the blend of $M D: A G$

Yellow-blue color $\left(b^{*}\right)$ : The yellow color parameter of the solutions of powder also decreased as the gum concentration increased $(12.58 \pm 0.12,11.84 \pm 0.85,10.74 \pm 0.72$ and $8.29 \pm 0.81$ for $0,3,5$ and $10 \%$, respectively, global averages).

$H u e\left(H^{\circ}\right)$. Regarding hue of solutions with different types of gums, the one with $M D$ had the lowest hue (19.93 \pm 0.54 , global average). About the concertation of gum, no differences ( $\mathrm{p}>0.05$ ) were observed among all solutions being $23.95 \pm 3.51,21.84 \pm 1.28$ and $21.57 \pm 1.86$ (global averages) for 3,5 and $10 \%$ of gum, respectively. The solutions of powder of $R E C(26.99 \pm 0.15$, global average) had greater hue $(H)$ than solutions of 5 and $10 \%$ of gum.

Purity $(C)$. The purity $(C)$ of the solutions from different types of gum did not show any significant difference $(\mathrm{p}>$ 0.05 ). About the gum concentration, the lowest purity was observed for the solutions of powders with $10 \%$ of gum. No significant differences ( $\mathrm{p}>0.05$ ) were observed within the solutions from 0,3 and $5 \%$ of gum: $27.71 \pm$ $0.13,29.61 \pm 3.74$ and $28.87 \pm 0.56$, respectively (global averages).

\subsubsection{Antioxidant Characteristics}

Table 6 shows the TMAs, TPCs, and ACs for RPs obtained with different carrier agents and concentrations.

Total monomeric anthocyanins (TMA). The content of TMAs showed no significant differences ( $\mathrm{p}>0.05)$ within the types of gums: $408.51 \pm 8.97,460.74 \pm 90.96,447.58 \pm 86.48$ and $404.55 \pm 55.03 \mathrm{mg} \mathrm{C}-3-\mathrm{G} / 100 \mathrm{~g}$ of dry 
powder for $R E C, G A, M D$ and $M D: G A$ (60:40), respectively (global averages). About the concentration of gums, the REC powder had lower amount of TMAs than powders with $3 \%$ of gum $(489.13 \pm 92.79 \mathrm{mg} \mathrm{C}-3-\mathrm{G} / 100 \mathrm{~g}$ of dry powder) (global average). No differences were observed in TMAs in powders with 5 and $10 \%$ of gum $(470.73 \pm 13.53$ and $353.01 \pm 16.31 \mathrm{mg} \mathrm{C}-3-\mathrm{G} / 100 \mathrm{~g}$ of dry powder, respectively, global average). TMAs of powders from $10 \%$ of gum had lower content of anthocyanins than powders with 3 and $5 \%$ of gum. It can be also observed that, when increasing the concentration of gums, the content of anthocyanins decreases which is very probably due to the amount of gum in the powder. Comparable results were observed by Cid-Ortega and Guerrero-Beltrán (2020) for powders of RECG of $H$. sabdariffa obtained by spray drying.

Table 6. Effect of the type and concentration of gums on the antioxidant properties of lyophilized Roselle powders $^{\mathrm{a}}$

\begin{tabular}{|c|c|c|c|c|}
\hline \multirow{2}{*}{$\begin{array}{l}\text { Gum } \\
\text { type }\end{array}$} & \multirow{2}{*}{$\begin{array}{l}\text { Gum } \\
(\% \mathrm{w} / \mathrm{w})\end{array}$} & $T M A^{b}$ & $T P C^{c}$ & $A C^{d}$ \\
\hline & & \multicolumn{3}{|c|}{ (mg/100 g powder) } \\
\hline$R E C$ & 0 & $408.51 \pm 8.97 \mathrm{a}$ & $4289.40 \pm 207.07 \mathrm{a}$ & $1722.40 \pm 40.54 a$ \\
\hline \multirow[t]{3}{*}{$G A$} & 3 & $560.93 \pm 10.13 b$ & $4179.60 \pm 69.52 \mathrm{ba}$ & $1612.60 \pm 25.40 \mathrm{bh}$ \\
\hline & 5 & $474.81 \pm 5.03 \mathrm{cf}$ & $3618.80 \pm 181.29 c$ & $1569.20 \pm 40.60 \mathrm{bcj}$ \\
\hline & 10 & $346.48 \pm 7.07 \mathrm{de}$ & $2529.20 \pm 115.66 d$ & $1486.20 \pm 23.71 d$ \\
\hline \multirow[t]{3}{*}{$M D$} & 3 & $543.46 \pm 15.68 b$ & $4004.00 \pm 105.35 b$ & $1766.30 \pm 31.15 \mathrm{a}$ \\
\hline & 5 & $458.02 \pm 15.81 \mathrm{c}$ & $3527.00 \pm 133.82 \mathrm{fc}$ & $1723.70 \pm 19.83 a$ \\
\hline & 10 & $341.27 \pm 14.50 \mathrm{~d}$ & $2760.70 \pm 136.18 \mathrm{gd}$ & $1571.60 \pm 70.50 \mathrm{bj}$ \\
\hline \multirow[t]{3}{*}{$M D: G A$} & 3 & $363.00 \pm 10.47 \mathrm{eg}$ & $4705.70 \pm 140.54 \mathrm{~h}$ & $1689.20 \pm 9.85 \mathrm{ahi}$ \\
\hline & 5 & $479.36 \pm 6.65 f$ & $4661.30 \pm 154.72 \mathrm{ih}$ & $1620.50 \pm 54.48 b i$ \\
\hline & 10 & $371.30 \pm 5.09 \mathrm{~g}$ & $3935.60 \pm 170.37 \mathrm{jb}$ & $1531.40 \pm 61.56 \mathrm{dj}$ \\
\hline
\end{tabular}

${ }^{a}$ Values with different letters within the same column have significant differences $(\mathrm{p} \leq 0.05) .{ }^{b}$ TMAs: total monomeric anthocyanins (cyanidin-3-glycoside equivalents). ${ }^{2} T P C s$ : total phenolic compounds (equivalents of gallic acid). ${ }^{3} A C$ : Antioxidant capacity (Trolox equivalents). REC: Roselle extract. GA: gum Arabic. MD: maltodextrin.

Total phenolic compounds (TPC). The content of TPCs (Table 6) regarding the type of gum was higher for the $R E C$ and $M D$ powders $(4,289.40 \pm 207.07$ and 4,434.20 $\pm 391.60 \mathrm{mg} G A E / 100 \mathrm{~g}$ powder, respectively) (global averages) in comparison to the TPCs of powders with $G A$ and $M D(3442.50 \pm 715.63$ and $3430.60 \pm 540.10 \mathrm{mg}$ $G A E / 100 \mathrm{~g}$, respectively) (global averages) gums. Regarding the gums concentration, a decrease in the content of TPCs was observed as the gum concentration increased $(4,296.40 \pm 323.44,3,935.70 \pm 549.70$ and 3,075.20 \pm $647.55 \mathrm{mg} \mathrm{GAE} / 100 \mathrm{~g}$ for 3, 5 and $10 \%$ of gum, respectively) (global averages). The content of TPCs for the $R E C$ powder was similar than for the concentrations of 3 and 5\% of gum, and higher than that of the $10 \%$ of concentration of gum.

Antioxidant activity (AC). The ACs (Table 6) concerning the type of gum was higher for the REC and $M D$ powders $(1,722.40 \pm 40.54$ and $1,687.20 \pm 96.21 \mathrm{mg} T E / 100 \mathrm{~g}$, respectively) (global averages) compared to the powders with $G A$ and $M D: G A(60: 40)(1,556.00 \pm 61.28$ and 1,613.70 $\pm 80.24 \mathrm{mg} T E / 100 \mathrm{~g}$, respectively) (global averages). For the gums concentration, a decrease in the ACs was observed as the gum concentration increases $(1,689.40 \pm 68.33,1,637.80 \pm 76.43$ and $1,529.70 \pm 63.49 \mathrm{mg} T E / 100 \mathrm{~g}$ of powder for 3,5 and $10 \%$ of gum, respectively) (global averages). The ACs of the REC powders was similar to that of the concentration of $3 \%$ and higher than that of the concentrations of 5 and $10 \%$ of gum.

\section{Conclusions}

The microencapsulation of extracts from Roselle calyces by lyophilization provided high yields, as well as powders with good antioxidant and color properties. The concentration of gum is an important aspect to consider in the encapsulation of extracts from Roselle. According to the results obtained, the extracts of Roselle microencapsulated with maltodextrin and gum arabic at a concentration of $3 \%$, allowed to obtain powders with the best antioxidant and color properties. Therefore, the use of microencapsulated powders obtained with these conditions signifies a viable option in the development of functional foods. However, it is recommended to carry out a stability study of the powders to determine the efficiency of the encapsulation process as well as the fading characteristics due to physical phenomena such as heat, oxygen, and light among others.

\section{Acknowledgments}

Sandro Cid-Ortega thanks the PRODEP (Programa para el Desarrollo Profesional Docente) and the UTIM 
(Universidad Tecnológica de Izúcar de Matamoros) for the scholarship granted for the completion of his doctoral studies.

\section{References}

AOAC. (1995). Official Methods of Analysis (14th ed.). Association of Official Analytical Chemists. Inc. Washington, D.C., USA.

AOAC. (2000). Official Methods of Analysis of AOAC International (17th ed.). Association of Official Analytical Chemists. Inc. Maryland, USA.

Brand-Williams, W., Cuvelier, M. E., \& Berset, C. (1995). Use of a free radical method to evaluate antioxidant activity. Lebensmittel-Wissenschaft und-Technologie, 28, 25-30. https://doi.org/10.1016/S0023-6438(95)80008-5

Cannon Instrument Company. (2014). Calculation of viscometer constants for Cannon-Fenske Routine and Cannon-Fenske Opaque Viscometers. State College, PA, USA. Retrieved from https://www.cannoninstrument.com/TechBrief101.pdf

Cannon Instrument Company. (2000). Certificate of calibration. Cannon-Fenske routine type for transparent liquids (standard test ASTM D 445, IP 71 and ISO 3104). State College, PA, USA.

Chumsri, P., Sirichote, A., \& Itharat, A. (2008). Studies on the optimum conditions for the extraction and concentration of Roselle (Hibiscus sabdariffa Linn.) extract. Songklanakarin Journal of Science and Technology, 30(1), 133-139.

Cid-Ortega, S., \& Guerrero-Beltrán, J. A. (2020). Microencapsulation of Hibiscus sabdariffa (Roselle) extracts by spray drying using maltodextrin and gum arabic as carriers. Journal of Food Research, 9(5), 53-66. https://doi.org/10.5539/jfr.v9n5p53

Comunian, T. A., Monterrey-Quintero, E. S., Thomazini, M., Balieiro, J. C. C., Piccone, P., Pittia, P., \& Favaro-Trindade, C. S. (2011). Assessment of production efficiency, physicochemical properties and storage stability of spray-dried chlorophyllide, a natural food colourant, using gum Arabic, maltodextrin and soy protein isolate-based carrier systems. International Journal of Food Science and Technology, 46, 1259-1265. https://doi.org/10.1111/j.1365-2621.2011.02617.x

Decagon Devices Inc. (2008). AquaLab water activity meter. Operator's manual for series 4TE, 4TEV, DUO (Version 7). Pullman, WA, Decagon Devices Inc.

Duangmal, K., Saicheua, B., \& Sueeprasan, S. (2004). Roselle anthocyanins as a natural food colorant and improvement of its colour stability. Proceedings of the AIC 2004 Color and Paints, Interim Meeting of the International Color Association. Porto Alegre, Brazil. pp. 155-158.

Ersus, S., \& Yurdagel, U. (2007). Microencapsulation of anthocyanin pigments of black carrot (Daucus carota L.) by spray drier. Journal of Food Engineering, 80, 805-812. https://doi.org/10.1016/j.jfoodeng.2006.07.009

Farimin, A. O. A., \& Nordin, E. (2009). Physical properties of powdered Roselle-pineapple juice-effects of maltodextrin. In M. M. Noor, M. M. Rahman, \& K. Kadirgama (Eds.), National Conference on Postgraduate Research (NCON-PGR) (pp. 90-97). Centre for Graduate Studies, University Malaysia Pahang.

Fazaeli, M., Emam-Djomeh, Z., Ashtari, A. K., \& Omid, M. (2012). Effect of spray drying conditions and feed composition on the physical properties of black mulberry juice powder. Food and Bioproducts Processing, 90, 667-675. https://doi.org/10.1016/j.fbp.2012.04.006

Gharsallaoui, A., Roudaut, G., Chambin, O., Voilley, A., \& Saurel, R. (2007). Applications of spray-drying in microencapsulation of food ingredients: An overview. Food Research International, 40, 1107-1121. https://doi.org/10.1016/j.foodres.2007.07.004

Goula, A. M., \& Adamopoulos, K. G. (2008). Effect of maltodextrin addition during spray drying of tomato pulp in dehumidified air: II. Powder properties. Drying Technology, 26, 726-737.

https://doi.org/10.1080/07373930802046377

HunterLab. (1991). HunterLab ISO 9001 Certified. Hunter Associates Laboratory, Inc. pp. 1-12.

Idham, Z., Muhamad, I. I., \& Sarmidi, M. R. (2012). Degradation kinetics and color stability of spray-dried encapsulated anthocyanins from Hibiscus Sabdariffa L. Journal of Food Process Engineering, 35, 522-542. https://doi.org/10.1111/j.1745-4530.2010.00605.x 
Janiszewska, E., \& Witrowa-Rajchert, D. (2009). The influence of powder morphology on the effect of rosemary aroma microencapsulation during spray drying. International Journal of Food Science and Technology, 44, 2438-2444. https://doi.org/10.1111/j.1365-2621.2009.02025.x

Jumah, R. Y., Tashtoush, B., Shaker, R. R., \& Zraiy, A. F. (2000). Manufacturing parameters and quality characteristics of spray dried jammed. Drying Technology, 18(4 \& 5), 967-984. https://doi.org/10.1080/07373930008917747

Lee, J., Durst, R. W., \& Wrolstad, R. E. (2005). Determination of total monomeric anthocyanin pigment content of fruit juices, beverages, natural colorants, and wines by the $\mathrm{pH}$ differential method: collaborative study. Journal of AOAC International, 88(5), 1269-1278. https://doi.org/10.1093/jaoac/88.5.1269

Lopez, B. E., Carvajal, L. M., \& Leonidas, M. C. (2009). Establecimiento de condiciones de la mezcla de pulpa de banano (Musa paradisiaca L.) para someter a secado por aspersión. Vitae, 16(3), 287-296.

Minitab Inc. (2003). Statistical software, Release 14.1 for Windows. State College, Pennsylvania. MINITAB®.

Muro, M. D., Lizaso, M. T., García, B. E., Acero, S., Olaguíbel, J. M., \& Tabar, A. I. (1997). Actividad biológica de extractos de frutas de la familia rosácea propios liofilizados. Comparación con extractos comerciales. Revista Española de Alergología e Inmunología Clínica, 12(4), 224-230.

NOM. (2001). NOM-104-STPS-2001: Norma Oficial Mexicana, Agentes extinguidores-Polvo químico seco tipo $A B C$ a base de fosfato mono amónico. Secretaria del Trabajo and Previsión Social, México, Distrito Federal.

O’Hagan, P., Hasapidis, K., Coder, A., Helsing, H., \& Pokrajac, G. (2005). Particle Size Analysis of Food Powders. In C. Onwulata (Ed.), Encapsulated and Powdered Foods (pp. 215-245). Boca Raton, FL, USA: CRC Press Taylor \& Francis Group. https://doi.org/10.1201/9781420028300-12

Özkan, G., \& Bilek, S. E. (2014). Microencapsulation of natural food colourants. International Journal of Nutrition and Food Sciences, 3(3), 145-156. https://doi.org/10.11648/j.ijnfs.20140303.13

Peng-Kong, W., Yusof, S., Ghazali, H. M., \& Che-Man, Y. B. (2002). Physico-chemical characteristics of Roselle (Hibiscus sabdariffa L.). Nutrition and Food Science, 32(2), 68-73. https://doi.org/10.1108/00346650210416994

Rajarajan, S., Asthana, M., \& Shanthi, G. (2010). In vitro bactericidal activity of lyophilized ethanolic extract of Indian almond (Terminalia catappa Linn.) fruit pulp on two pathogenic bacteria from subgingival plaques. Indian Journal of Natural Products and Resources, 1(4), 466-469.

Salazar-González, C., Vergara-Balderas, F. T., \& Guerrero-Beltrán, J. A. (2009). Evaluación de agentes antioxidantes de un extracto de flor de Jamaica microencapsulado. Temas Selectos de Ingeniería de Alimentos, 3(2), 14-25.

Santos, D. T., \& Meireles, M. A. (2010). Carotenoid pigments encapsulation: fundamentals, techniques and recent trends. The Open Chemical Engineering Journal, 4, 42-50. https://doi.org/10.2174/1874123101004010042

Selim, K. A., Khalil, K. E., Abdel-Bary, M. S., \& Abdel-Azeim, N. A. (2008). Extraction, encapsulation and utilization of red pigments from Roselle (Hibiscus sabdariffa $L$.) as natural food colourants. Special Volume Conference. Alexandria Journal of Food Science and Technology. Alexandria University. Alexandria, Egipto. pp. 7-20. https://doi.org/10.21608/ajfs.2008.19642

Silva, P. I., Stringheta, P. C., Teófilo, R. F., \& Nolasco de Oliveira, I. R. (2013). Parameter optimization for spray-drying microencapsulation of jaboticaba (Myrciaria jaboticaba) peel extracts using simultaneous analysis of responses. Journal of Food Engineering, 117(4), 538-544. https://doi.org/10.1016/j.jfoodeng.2012.08.039

Singleton, V. L., \& Rossi, J. A. (1965). Colorimetry of total phenolic with phosphomolybdic-phosphotungstic acid reagents. American Journal of Enology and Viticulture, 16(3), 144-158.

Tonon, R. V., Freitas, S. S., \& Hubinger, M. D. (2011). Spray drying of açai (Euterpe oleraceae Mart.) juice: effect of inlet air temperature and type of carrier agent. Journal of Food Processing and Preservation, 35, 691-700. https://doi.org/10.1111/j.1745-4549.2011.00518.x

Viloria-Matos, A., Corbelli-Moreno, D., Moreno-Alvarez, M. J., \& Belén, D. R. (2002). Estabilidad de betalainas en pulpa de tuna (Opuntia boldinghii Br. et R.) sometidas a un proceso de liofilización. Revista de la Facultad de Agronomía (LUZ), Carabobo, Venezuela, 19, 324-331. 
Zhang, L., Mou, D., \& Du, Y. (2007). Procyanidins: Extraction and microencapsulation. Journal of the Science of Food and Agriculture, 87, 2192-2197. https://doi.org/10.1002/jsfa.2899

\section{Copyrights}

Copyright for this article is retained by the author(s), with first publication rights granted to the journal.

This is an open-access article distributed under the terms and conditions of the Creative Commons Attribution license (http://creativecommons.org/licenses/by/4.0/). 